\title{
Pollen grains and seed morphology as related to biochemical patterns in five species of genus Ocimum L. (Lamiaceae Juss.) of Saudi Arabia
}

\author{
Wael Taha Kasem ${ }^{1,2 *}$ \\ 'Department of Botany and Microbiology, Faculty of Science, Al-Azhar University, Egypt, ${ }^{2}$ Department of Biology, Faculty of Science, \\ Jazan University, KSA
}

Received: 15.11 .2016

Revised: 18.12 .2016

Accepted: 01.12 .2016

Published: 30.12 .2016

*Address for

correspondence:

Wael Taha Kasem,

Department of Botany and

Microbiology, Faculty of

Science, Al-Azhar University,

Egypt. E-mail: wael_kasm@

yahoo.com

\begin{abstract}
This study aims to investigate the pollen and seed morphology by light microscopy (LM) and scanning electron microscope (SEM) as related to biochemical data of seed protein and esterase isoenzymes by sodium dodecyl sulfate-polyacrylamide gel electrophoresis technique (SDS-PAGE) in the five Saudi Arabian Ocimum L. species. The detailed description for pollen and seed morphology in addition electrophoretic patterns were represented by means of numerical analyses based on total 39 studied characters. The pollen grains were zonocolpate, hexacolpate, and prolate to subprolate, with bireticulate tetctum in all the studied species. The types of exine ornamentation were recognized, perforate, reticulate, and granulate. In seed morphology, the anticlinal cell wall boundaries and periclinal cell walls are described by the aid of SEM which exhibited four main distinct types of nutlets sculpture, undulate, quirky, circular, and straight. On the other hand, the molecular patterns of protein profiles and esterase (EC.3.1.1.1) showed that esterase could be considered as positive markers, minimum and maximum gene/gene expression of protein profiles and esterase isoenzymes demonstrated. An constructed artificial keys and the relationships between the studied species were elucidated.
\end{abstract}

KEY WORDS: Lamiaceae; Ocimum; Palynology; Seed morphology; Seed Proteins; Esterase isoenzymes

\section{INTRODUCTION}

Genus Ocimum L. (tribe Ocimeae) is one of the largest genera Lamiaceae Juss; it comprise about 150 species mainly in tropical and warm temperate countries. Six species of Ocimum L. are recorded in Saudi Arabia (Al-Farhan et al., 2005; Masrahi, 2012). Palynology has been used considerably in the angiosperms taxonomy and helped in tracing the history of plant groups and species (Moore and Webb, 1978). Patel and Datta (1958) and Sowunmi (1973) are some of the researchers who have worked on the pollen grains morphology and emphasized their significance architecture in phylogeny. Bentham (1832) divided the Ocimum into three sections; Ocimum (Ocymodon Benth.), Hierocymum Benth and Gymnocymum Benth. Pollen grains of three species and a variety of Ocimum occurring in South-western Nigeria by light microscopy (LM) have been reported by Arogundade and Adedeji (2009). Morphological characteristics of family Lamiaceae of seeds of Al-Taif in Saudi Arabia are focused by Hassan and Altobatti (2015) and formerly by
El-Gazzar andWatson (1970). The protein electrophoretic separations now have an established place in modern chemotaxonomic practice (Harborne and Turner, 1984). Genetic diversity among Ocimum L. populations in Egypt as reflected by morphological and electrophoretic techniques are carried out by Abd El-Zaher et al. (2006). Current work aims to describe in details the pollen and nutlet morphology (macro and micro characters) of five Ocimum L. species in Saudi Arabian by light microscopy (LM) and scanning electron microscopy (SEM) and their correlations to the biochemical analyses to give modern data may can support to evaluate the systematic relationships of this species in genus Ocimum.

\section{MATERIALS AND METHODS}

Five species of Ocimum L., were collected from different localities in Jazan area of Saudi Arabia as follows: Ocimum americanum L., Jabal Fayfa; Ocimum basilicum, Al-Arda; Ocimum filamentosum Forssk., Jabal Fayfa; Ocimum forsskalii Benth, near Bani Malik and Ocimum tenuiflorum L.,

Journal of Phytology • Vol 8 • 2016 
Al-Arda. Specimen identification was identified according to Chaudhary (2001) and Al-Farhan et al., 2005, the voucher specimens are deposited at the Jazan University Herbarium, KSA (JAZUH).

\section{Pollen Morphology}

Pollen grains of the taxa were studied by LM and SEM, for LM, pollen grains were first treated with $70 \%$ alcohol to remove oily substances. For LM, the pollen grains were observed and photographed by a Nikon E1100 microscope. The measurements are based on 20 readings from each slide. The polar axis $(\mathrm{P})$, equatorial diameter $(\mathrm{E})$, and $\mathrm{P} / \mathrm{E}$ ratio were calculated. For SEM, acetylation was according to the Erdtman technique (Erdtman, 1952). Pollen grains were dehydrated in ethanol sequences and mounted on a metallic stub in few drops of ethanol. The specimens were coated with gold in Apolaron E1 100 ion sputtering device, then viewed at $20 \mathrm{KV}$ in a JOEL JSM 5300 SEM of the Central Laboratory, Faculty of Science, Alexandria University, Egypt. The terminology based on Barthlott $(1981 ; 1984)$.

\section{Seed Morphology}

Mature seeds of the five species were collected from their natural habitats. 10 seeds of each species were examined for size, shape, and color. During SEM, mature seeds (2-3) from each species were selected and mounted onto stubs with double-sided adhesive tape and coated with gold. The seed surface pattern was examined on the lateral surfaces of the seeds. For each sample, photographs of seeds were taken using a $20 \mathrm{KV}$ in a JOEL JSM 5300 at different magnifications powers and photomicrography. The terminology used here follows authors such as Stearn (1992), Barthlott (1981), and Koul et al. (2000).

\section{Electrophoretic Techniques}

Species Seeds were collected, washed in distilled water, dried and ground to fine powder and used for protein and isoenzyme determination. Sodium dodecyl sulfatepolyacrylamide gel electrophoresis (SDS-PAGE) was conducted as the method outlined by Stegemann et al. (1988). Bands were determined and scanned using Hoefer scanning densitometer GS 300. Protein gel bands scanned and photographed. Homogeneous PAGE was conducted for esterase isoenzyme measurements as outlined by Stegemann et al. (1988). After electrophoretic process; the specific staining solution used according to Graham et al. (1964) and Jonathan and Wendel (1990). The esterase gel is stained by adding $1 \mathrm{ml}$ of $1 \%$ alpha naphthyl acetate in $60 \%$ acetone to $25 \mathrm{ml}$ phosphate buffer (pH 6.5) and $10 \mathrm{mg}$ of fast blue RR were added to $50 \mathrm{ml}$ of the same buffer. Gel scanned using also Hoefer scanning densitometer GS 300.

\section{Data Analysis}

A statistical analysis of the identified data was carried out by multivariate cluster analysis using using Minitab 13.1 release-PC computer program (Minitab 2000). A table illustrating the means of all parameters was prepared, cluster diagram of the total values was constructed.

\section{RESULTS AND DISCUSSION}

\section{Pollen Grain Characters}

Two types of pollen grains were observed, prolate or subprolate, hexacolpate shape, Colpi is fissure-like or slitlike apertures (furrows) (Figure 1). In exine examination, tectum in all examined species is doubly-reticulate.

\section{O. americanum $L$.}

The pollen types were subprolate, with concave form. Polar length ranged in between 25.3 and $27.7 \mu \mathrm{m}$, and the equatorial one was 18.3-19.2 $\mu \mathrm{m}$ with an average $\mathrm{P} / \mathrm{E}$ ratio of $1.42 \mu \mathrm{m}$. Pollen wall thickness ranged from 5.93 to $6.24 \mu \mathrm{m}$. Doubly reticulate (bi-reticulate) tectum has a distinctive regular primary and secondary stratum. Coarsely perforate structure with enlarge pores were noticed in secondary lumina (substratum) (Figure 2 - $1 \mathrm{a}$ and b).

\section{O. basilicum $L$.}

Possessed prolate, with convex-shaped pollen grains. The polar axis was 21-23 $\mu \mathrm{m}$ while the equatorial one was 13-17 $\mu \mathrm{m}$, and the average $\mathrm{P} / \mathrm{E}$ ratio was $1.5 \mu \mathrm{m}$. Thick pollen walls of 7.93-8.42 $\mu \mathrm{m}$ were noticed. The tectum examination by SEM showed bireticulate patterns and deep with regular rough granular particles in the inner part of substratum (Figure 2 - 2a and b).

\section{O. filamentosum Forssk.}

The observed pollen type was subprolate (Figure 1 - 3a and $b$ ), with concave shape. Six apertures were situated in both the polar and equatorial regions. The polar and equatorial lengths were 26.4-27.3 $\mu \mathrm{m}$ and 21.7-22.5 $\mu \mathrm{m}$, respectively, with mean $\mathrm{P} / \mathrm{E}$ ratio of $1.22 \mu \mathrm{m}$, wall thickness in between 7.93 and $8.42 \mu \mathrm{m}$. SEM revealed a regular tectum; primary lumina has a smooth wall texture, and regular reticulate structure was common in the secondary lumina (Figure $2-3 a$ and $b$ ).

\section{O. forsskalii Benth.}

Hexacolpate pollen type was observed, subprolate, ovoidal to spherical shape, concave. Fairly large pollen grains found. The polar length was 32.1-34.3 $\mu \mathrm{m}$ while equatorial length was 26.3-27.4 $\mu \mathrm{m}$, and $\mathrm{P} / \mathrm{E}$ ratio was $1.31 \mu \mathrm{m}$. Thick pollen wall (8.6-9.2 $\mu \mathrm{m})$ was estimated. Exine structure explained a fairly deep tectum with rough stratum; the 


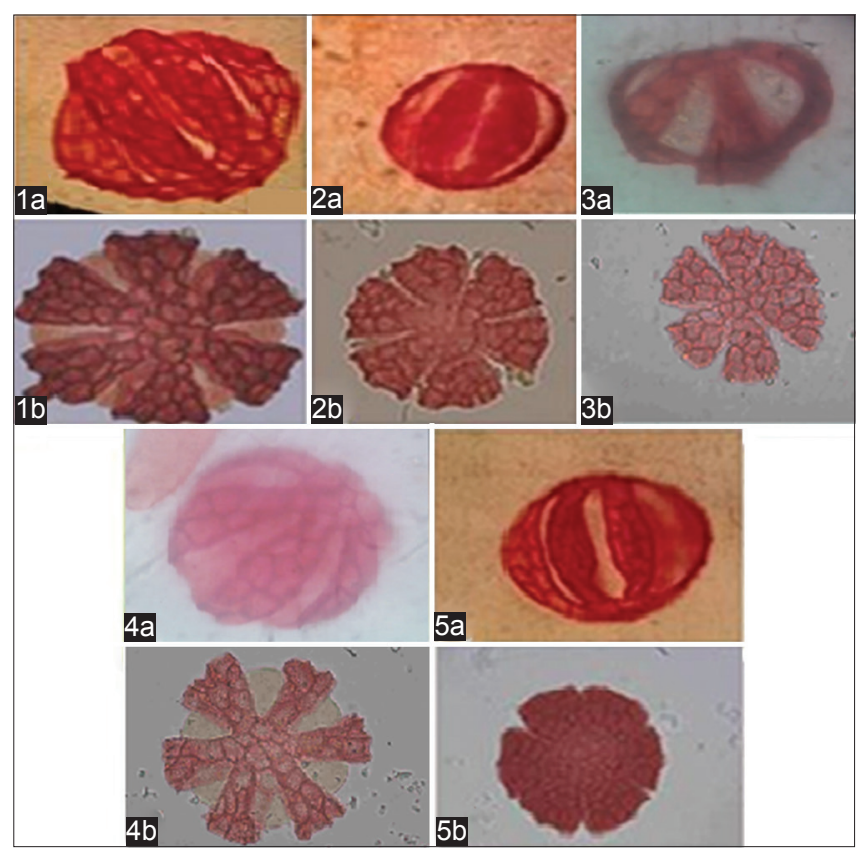

Figure 1: Light microscopy photographs of pollen grains of the studied species, (a) Equatorial view, (b) polar view. (1 a \& b) O. americanum; (2 a \& b) O. basilicum; ( 3 a \& b) O. filamentosum; ( 4 a \& b) O. forsskalii and $(5 \mathrm{a} \& \mathrm{~b}) \mathrm{O}$. tenuifl orum $(\times 1000)$

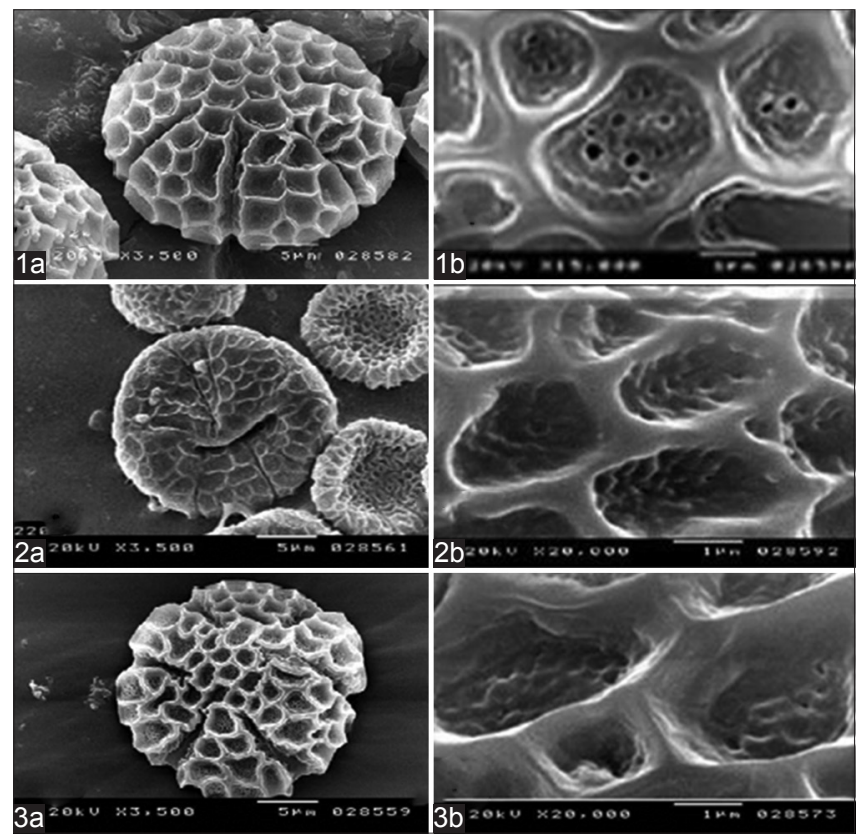

Figure 2: Scanning electron microscope micrographs of pollen grains. (a) Polar view; (b) enlargement part of exine; (1 a \& b) O. americanum; (2 a \& b) O. basilicum; (3 a \& b) O. filamentosum.

secondary lumina filled with very finely perforation form and semi-solid structure (Figure 3 - 4a and b).

\section{O. tenuiflorum $L$.}

Subprolate, hexacolpate, spheroidal type of pollen grains was found. Polar length of 24.9-25.8 $\mu \mathrm{m}$ and equatorial length of 19.1-22.8 $\mu \mathrm{m}$ were found. P/E ratio was 1.19. The thickness of the pollen wall was 7.8-8.3 $\mu \mathrm{m}$. Pollen tectum was angular and deep, stratum has a smooth texture whereas the substratum filled with irregular perforate patterns (Figure $3-5 a$ and $b$ ).

Key to the studied species based on pollen microsculpture

\begin{tabular}{ll}
\hline A1 - Pollen grains are prolate & 0. basilicum \\
A2 - Pollen grains are subprolate & \\
B1 - Substratum is rugose patterns & 0. filamentosum \\
B2 - Substratum is perforate shaped & \\
C1 - Rough perforation with regular pattern & 0. americanum \\
C2 - Coarsely perforate with irregular pattern & 0. tenuiflorum \\
C3 - Finely perforate with semi-solid structure & 0. forsskalii \\
\hline
\end{tabular}

\section{Seed Morphology and Seed Coat Sculpturing}

Macro- and micro-morphological seed parameters of the five species as shown by LM and SEM are illustrated and photographed.

\section{Ocimum americanum $L$.}

Slightly large seeds $(1.5-1.6 \times 0.77-0.79 \mathrm{~mm})$ with smooth texture. Ellipsoid-oblong in shape with upper and basal rounded ends with short projection. Seed color is gray to black. Nutlet coat sculpture revealed thin anticlinal walls, undulate with regular polygonal fork form and raised boundaries. periclinal cell walls are smooth fairly concave form (Figure 4 - $1 \mathrm{a}$ and $\mathrm{b}$ ).

\section{O. basilicum $L$.}

Seeds $(1.30-1.35 \times 0.4-0.50 \mathrm{~mm})$ with smooth texture, gray color, ellipsoid-ovate with upper rounded end in which a short projection appeared while basal end is oval. The examined anticlinal cell wall boundaries, demonstrate a fairly finely raised, quirky polygonal cells. Periclinal cell walls are smooth and fairly convex. (Figure 4 - 2a and b).

\section{O. filamentosum Forssk.}

Seed size, 1.1-1.5 $\times$ 0.3-0.4 mm, rough texture, black nutlet. Ellipsoid oblong-oval shape with oval upper end and short projection while seed basal end is rounded. Seed scan by SEM showed a thin anticlinal cell walls with undulated polygonal depressed deformation boundary cells. Smooth irregular periclinal cells, convex with compactly reticulated patterns. (Figure $4-3 a$ and $b$ ).

\section{O. forsskalii Benth.}

Seed diameter, 1.4-1.45 × 0.77-0.78 mm. Black nutlet, rough texture, oblong-ovoid. Seed upper end is oval with short projection whereas the lower end is circular. 
Anticlinal walls are, rough and raised with circular boundary cells. Periclinal cells are convex filled with consistent granulated particles (Figure 5 - $4 \mathrm{a}$ and b).

\section{O. tenuiflorum $L$.}

Seeds fairly small, 1.1-1.2 $\times$ 0.8-0.9 mm, not hairy rough texture, oval-ellipsoid shape, dark brown with upper round end, and long projection. Nutlet lower end was ovoid. SEM revealed irregular ornamentation on the surface, The anticlinal walls are straight, and undulated with depressed, boundary cells. Periclinal cell walls are concave and smooth (Figure $5-5 a$ and $b$ ).
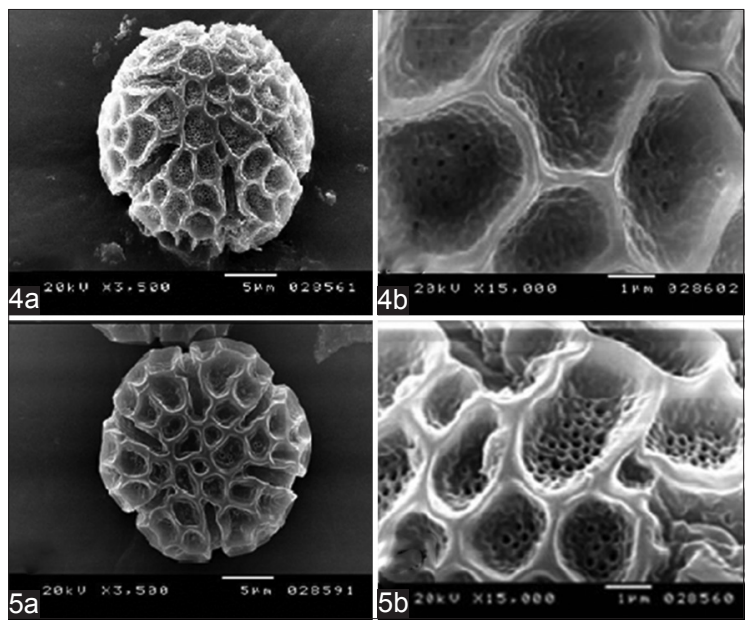

Figure 3: Scanning electron microscope micrographs of pollen grains. (a) Polar view; (b) enlargement part exine; (4 a \& b) O. forsskalii, (5 a \& b) O. tenuifl orum
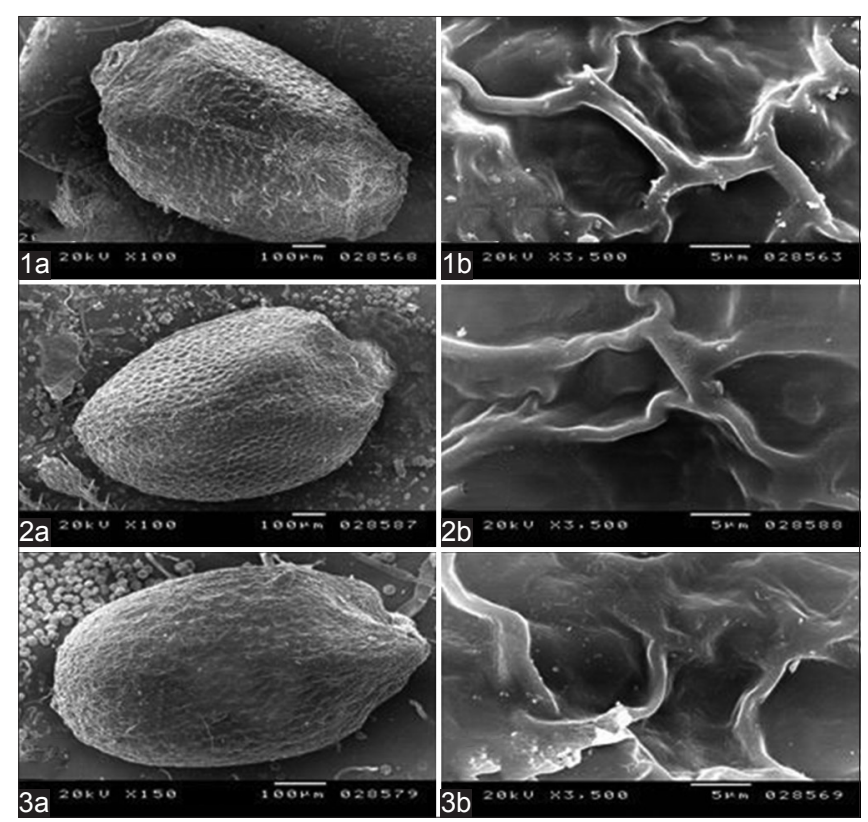

Figure 4: Scanning electron microscope micrographs of seed surface sculpture. (a) Mature seed, (b) enlargement of seed coat. (1 a \& b) $O$. americanum; (2 a\& b) O. basilicum; (3 a\& b) O. filamentosum.
Key to the studied species based on seed coat sculpture

\begin{tabular}{ll}
\hline A1 - Anticlinal walls are rough with & 0. forsskalii \\
circular boundary cells & \\
A2 - Anticlinal walls are smooth & \\
B1 - Depressed boundary cells & \\
C1 - Thin polygonal deformated cells & 0. filamentosum \\
C2 - Finely irregular straight cells & 0. tenuiflorum \\
B2 - Raised boundary cells & \\
D1 - Regular with fork-shaped & 0. americanum \\
D2 - Regular with undulated shaped & 0. basilicum \\
\hline
\end{tabular}

\section{Biochemical Characters}

\section{Seed protein profiles and esterase (EC.3.1.1.1) isoenzymes}

Protein and esterase electrophoretic patterns for the five species of Ocimum are presented inTable 1 and illustrated in Figure $6 \mathrm{a}$ and $\mathrm{b}$. From gel scan, ten protein groups obtained with migration distances ranged from 0.80 to $4.78 \mathrm{~mm}$. Protein bands of $1,3,5,7$, and 10 (monomorphic) found in all the studied species. The highest number of nine protein profile found in O. basilicum whereas the lowest one was noticed in O.forsskalii (Figure 6a). On the other hand, eight esterase patterns obtained scanning the gel with migration distances in between 0.78 and $5.43 \mathrm{~mm}$. These profiles revealed that Est 2, Est 5, and Est 8 pattern were found in all species. The highest number of eight esterase isoenzyme bands found in O. basilicum whereas the lowest one of three bands noticed in O. tenuiflorum.

39 different characters (Table 1) included pollen grains, seed morphology and electrophoretic polymorphism of seed protein and esterase isoenzymes used in cluster analysis (Figure 7). From the phenogram, O. basilicum separated in a single level than the remainders which gathered at the different similarity level. In the second

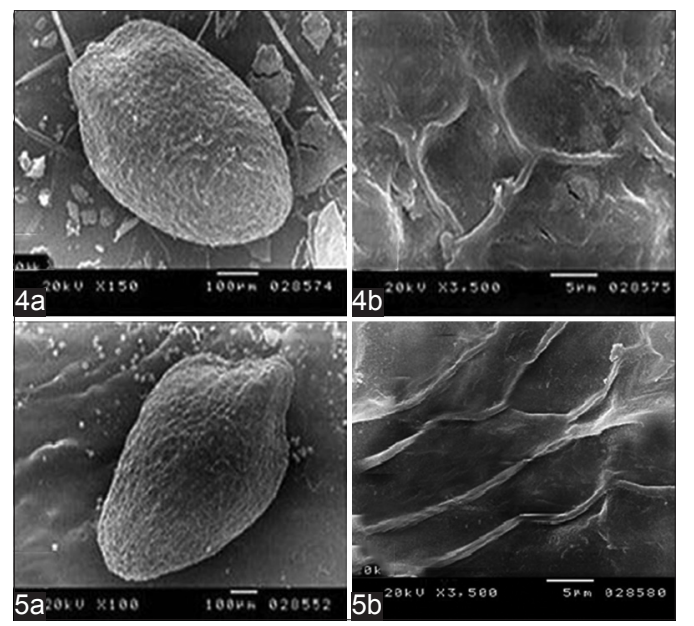

Figure 5: Scanning electron microscope micrographs of seed surface sculpture. (a) Entire mature seed; (b) seed coat microsclpture. (4 a\& b) O. forsskalii, and ( $5 \mathrm{a} \& \mathrm{~b})$ O. tenuifl orum. 


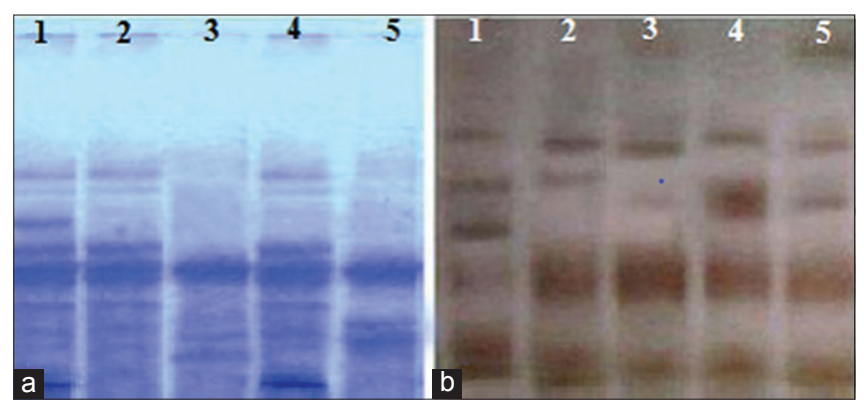

Figure 6: Sodium dodecyl sulfate-polyacrylamide gel electrophoresis illustrating seed protein bands (a) and esterases bands (b) of the studied species. (1) O. americanum, (2) O. basilicum, (3) O. filamentosum, (4) O. forsskalii, (5) O. tenuiflorum

subgroup, O. filamentosum and O. tenuiflorum grouped in an alone cluster. The highest similarity level between $O$ americanum and $O$. forsskalii. It is noticed that, Ocimum pollen looked similar in LM, where the pollen of all the species were spherical to ovoidal, hexacolpate were encountered, this result agrees with the conclusions of Moore and Webb (1978) and Madeline et al. (1992). The highest $\mathrm{P} / \mathrm{E}$ ratio $(1.42 \mu \mathrm{m}$, ) was recorded in of $O$. americanum while the lowest one $(1.06 \mathrm{~mm})$ was in $O$. basilicum. In pollen ultrastructure, bireticulated form was appeared; the primary lumina (stratum) and a secondary one (substratum) differed in all the species. Granulated lumina in $O$. basilicum, perforated form in $O$. americanum and O.forsskalii and O. tenuiflorum, reticulated-rugose in $O$. filamentosum in accordance with those of Madeline et al. (1992) and Harley et al. (1992). The seed micro- and macromorphological parameters showed that nutlet is fairly variable in shape and size. Ellipsoid shape was observed in all the studied species such variability in seed shapes existed a within a given species agree with Mayer and Mayber (1975) and Hassan and Altobatti (2016). Seed color ranged from dark brown, gray or black; Husain et al. (1990) and Hussein (2000) considered the seed color as having a very limited taxonomic value in this genus because it is fairly similar color. In dimensions' measurements, obtained results showed fairly range of variations in nutlets size, so, the color, shape, and size can be of little taxonomic important. Similar conclusions have also been given by Karakish (1993), Hamed and Mourad (1994), Shaheen (2002), Kaya and Dirmencl (2008), Budantsev (1993), and Kasem (2016). Periclinal and anticlinal wall discriminated in certain species such as undulate in Americanum and $O$. filamentosum, quirky in $O$. basilicum, rounded in $O$. forsskalii and straight in O. tenuiflorum. On the other hand, molecular patterns in seed protein and esterase isoenzymes differed in band numbers and migration distance. The highest protein bands found in $O$. americanum whereas minimum bands found in $O$.
Table 1: Pollen and seed morphology, seed protein and esterase isoenzymes data used in cluster analysis between the five studied species

\begin{tabular}{llllll}
\hline Total parameters & \multicolumn{5}{c}{ Species } \\
\cline { 2 - 4 } & 1 & 2 & 3 & 4 & 5
\end{tabular}

Pollen grain characters

Apertures type

1 - Colpate, 2 - Acolpate $\quad \begin{array}{lllll}1 & 1 & 1 & 1 & 1\end{array}$

Aperture number

1 - Hexacolpate, 2 - Not hexcolpate $\quad \begin{array}{lllll}1 & 1 & 1 & 1 & 1\end{array}$

Pollen type

A - 1 - Subprolate, 2 - prolate

B - 1 - Convex, 2 - Concave

$\begin{array}{lllll}1 & 2 & 1 & 1 & 1\end{array}$

Polar axis $(\mathrm{P} \mu \mathrm{m})$

$1-\leq 27 \mu \mathrm{m}, 2$ - $\geq 28 \mu \mathrm{m}$

Equatorial axis (E $\mu \mathrm{m})$

1 - $\leq 19 \mu \mathrm{m}, 2-\geq 20 \mu \mathrm{m}$

$\mathrm{P} / \mathrm{E}$ ratio

$1-\leq 1.24 \mu \mathrm{m}, 2$ - $\geq 1.22 \mu \mathrm{m}$

Pollen wall thickness $(\mu \mathrm{m})$

1 - Thin, 2 - Thick

Tectum

1 - Reticulate, 2 - Bireticulate

Primary lumina (stratum)

1 - Superficial, 2 - Deep

Secondary lumina (substratum)

1 - Perforate, 2 - Reticulate, 3 - Granulate

Seed morphology characters

Seed shape

1 - Ellipsoid, 2 - Not ellipsoid

Seed color

1 - Black, 2 - Gray, 3 - dark brown

Seed size $(\mathrm{mm})$

1 - Small, 2 - Large ( $\leq 1.3 \times 0.7 \mathrm{~mm})$

Seed texture

1 - Smooth, 2 - Rough

Seed projection

1 - Long, 2 - Short

$\begin{array}{lllll}2 & 1 & 2 & 2 & 2\end{array}$

$\begin{array}{lllll}1 & 1 & 1 & 2 & 2\end{array}$

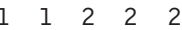

$\begin{array}{lllll}1 & 1 & 2 & 1 & 2\end{array}$

$\begin{array}{lllll}2 & 1 & 1 & 1 & 1\end{array}$

$\begin{array}{lllll}2 & 2 & 2 & 2 & 2\end{array}$

$\begin{array}{lllll}1 & 1 & 2 & 2 & 2\end{array}$

$\begin{array}{lllll}1 & 3 & 1 & 2 & 1\end{array}$

Periclinal wall

A - Level

1 - Convex, 2 - Concave

B - Texture

1 - Smooth, 2 - Rough

C - Shape

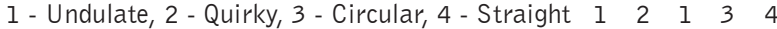
Anticlinal wall

A - Level

1 - Raised, 2 - Depressed

B - Thickness

1 - Thin, 2 - Thick

Migration distance of protein (Pro)

Pro. 1: 1 - Present, 2 - Absent

Pro. 2: 1 - Present, 2 - Absent

Pro. 3: 1 - Present, 2 - Absent

Pro. 4: 1 - Present, 2 - Absent

Pro. 5: 1 - Present, 2 - Absent

Pro. 6: 1 - present, 2 - absent

Pro. 7: 1 - present, 2 - absent

Pro. 8: 1 - present, 2 - absent

Pro. 9: 1 - present, 2 - absent

Pro 10: 1 - present, 2 - absent

Migration distance of esterase (Est)

EST 1.1 - Present, 2 - Absent

EST 2. 1 - Present, 2 - Absent

EST 3. 1 - Present, 2 - Absent

EST 4.1 - Present, 2 - Absent

EST 5.1 - Present, 2 - Absent $\begin{array}{lllll}1 & 1 & 2 & 1 & 1\end{array}$

$\begin{array}{lllll}1 & 1 & 1 & 2 & 1\end{array}$

$\begin{array}{lllll}1 & 1 & 1 & 1 & 1\end{array}$

$\begin{array}{lllll}2 & 1 & 2 & 2 & 2\end{array}$

$\begin{array}{lllll}1 & 1 & 1 & 1 & 1\end{array}$

$\begin{array}{lllll}1 & 1 & 2 & 2 & 1\end{array}$

$\begin{array}{lllll}1 & 1 & 1 & 1 & 1\end{array}$

$\begin{array}{lllll}1 & 2 & 2 & 1 & 2\end{array}$

$\begin{array}{lllll}1 & 1 & 1 & 1 & 1\end{array}$

$\begin{array}{lllll}1 & 2 & 1 & 2 & 1\end{array}$

$\begin{array}{lllll}1 & 1 & 1 & 2 & 2\end{array}$

$\begin{array}{lllll}1 & 1 & 1 & 1 & 1\end{array}$

$\begin{array}{lllll}1 & 1 & 2 & 1 & 2\end{array}$

$\begin{array}{lllll}1 & 1 & 1 & 1 & 1\end{array}$

$\begin{array}{lllll}1 & 1 & 1 & 1 & 1\end{array}$

$\begin{array}{lllll}1 & 2 & 2 & 1 & 2\end{array}$

$\begin{array}{lllll}1 & 1 & 1 & 1 & 1\end{array}$

(Contd...) 
Table 1: (Continued)

\begin{tabular}{llllll}
\hline Total parameters & \multicolumn{5}{c}{ Species } \\
\cline { 2 - 6 } & 1 & 2 & 3 & 4 & 5 \\
\hline EST 6. 1 - Present, 2 - Absent & 1 & 2 & 1 & 1 & 1 \\
EST 7. 1 - Present, 2 - Absent & 2 & 1 & 2 & 2 & 2 \\
EST 8. 1 - Present, 2 - Absent & 1 & 1 & 1 & 1 & 1 \\
\hline
\end{tabular}

1 - 0. americanum, 2 - 0. basilicum, 3 - 0. filamentosum, 4 - 0.forsskalii, 5 - 0. tenuiflorum

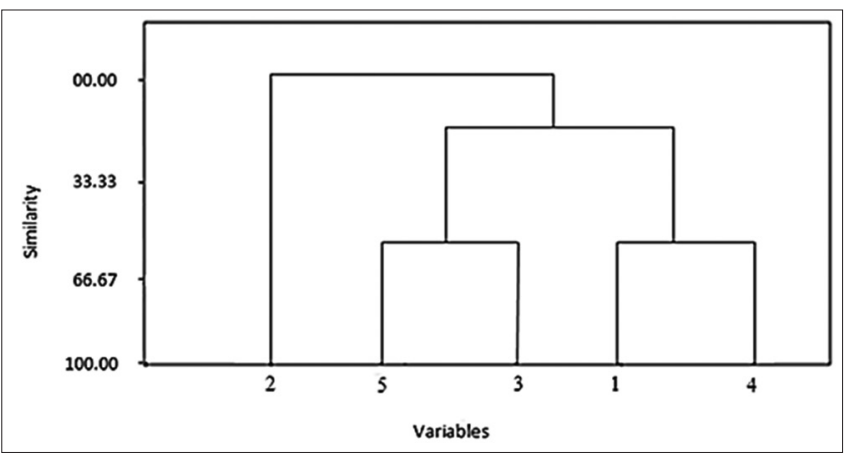

Figure 7: Phenogram based on 39 criteria of pollen grains, seed morphology and electrophoretic polymorphism of seed protein and esterase isoenzymes. (1) Ocimum americanum, (2) Ocimum basilicum, (3) Ocimum filamentosum, (4) Ocimum forsskalii, (5) Ocimum tenuiflorum

forsskalii The highest number (7 esterase bands) was recorded in O. americanum and $O$. forsskalii which gave the maximum gene/gene expression of esterase isoenzyme while minimum gene/gene expression was found in $O$. filamentosum and O.tenuiflorum. Exceptional being the protein bands No.1, 3, 5, 7, and 10 (monomorphic), were presented in all taxa and may be considered positive markers and the monomorphic esterase bands (Est 2, Est 5 and Est 8) were recorded in all species. Moreover, Abd El-Zaher et al. (2006) exhibited $O$. basilicum with unique alleles than other species in their studies of genetic diversity; these data are support my current work in the delimitation of the species in a separate level (Figure 7). Current data support the view of Bentham (1832 and 1848), who put O. americanum, O. basilicum, O. forsskalii in Ocimum (Ocymodon Benth). O. tenuiflorum in section Herocymum sub-section Foliosa. $O$. filamentosum which not treated in earlier classification, existent data would suggest putting this species in section Ocimum subsection Ocimum.

\section{ACKNOWLEDGMENT}

The author would like to thank the Biology Department, Faculty of Science, Jazan University, KSA for all their efforts and facilities and thanks to dr. Ahmed Shabasy for helping me in sample collecting and his facility in Alexandria University, Egypt.

\section{REFERENCES}

Al-Farhan AH, Al Turky TA, Basahy AY. Flora of Jizan Region. Final Report Supported by King Abdulaziz City for Science and Technology. Vol. 1 and Vol 2. 2005. p. 545.

Arogundade O, Adedeji O. Pollen grain morphology of three species and varieties of Ocimum L.(Lamiaceae) in South Western Nigeria. J Sci Technol 2009;29:1-7.

Barthlott W. Epidermal and seed surface characters of plants: Systematic applicability and some evolutionary aspects. Nord J Bot 1981;1:345-55.

Barthlott W. Microstructural features of seed surface. In: Heywood VH, Moore DC, editors. Current Concepts in Plant Taxonomy. Cambridge: Academic Press; 1984. p. 95-105.

Bentham G. Ocimum. In: de Candolle AP, de Candolle AL, editors. Prodromus Systematis Naturalis i RegniVegetabilis. Vol. 12. Paris: Treuttel et Wurtz; 1848. p. 3144.

Bentham G. Ocimum. In: Labiatarum Genera et Species. London: Ridgeway \& Sons; 1832. p. 1-19.

Budantsev AL. The ultra-structural features of fruit surface in some genera of tribe Nepeteae (Lamiaceae). Bot Zh 1993;78:100-8.

Chaudhary SA. Flora of the Kingdom of the Saudi Arabia. Vol. II. Riyadh: Ministry of Agriculture and Water; 2001. p. 342-354.

El-Gazzar A, Watson LA. Taxonomic study of Labiatae and related genera. New Phytol 1970;69:451-86.

Erdtman G. Pollen Morphology and Plant Taxonomy of Angiosperms. Stockholm: Almqvist and Wiksell; 1952. p. 539.

Graham RC, Lundholm U, Kamovsky MJ. Cytochemical demonstration of peroxidase activity with 3-amino-9ethylcarbazole. J Histochem Cytochem 1964;13:150-2.

Hamed KA, Mourad MM. Seed exomorphic and anatomical characters of some species of Convolvulaceae. Egypt J Bot 1994;34:1-16.

Harborne J, Turner BL. Plant chemosystematics. San Diego, California, USA: Academic Press; 1984.

Harley MM, PatonA, Harley RM, Cade PG. Pollen morphological studies in tribe Ocimeae (Nepetoideae: Labiatae): I. Ociniiinr L. Grana 1992;31:161-76.

Hassan SA, Altobatti A. Morphological untlet characterstics of some taxa in Saudi Arabia and their taxonomic significance. Pak J Bot 2015;47:1969-77.

Husain PD, Marin ŠC, Qaiser M, Petcovic BA. Micro morphological study of some representative genera in the tribe Saturejeae (Lamiaceae). Bot J Linn Soc 1990;103:59-80.

Hussein HA. Taxonomical and phylogenetic implications of nutlet morphology in some members of subfamily 
Boraginoideae (Family, Boraginaceae). J. Union Arab Biol 2000;10:41-52.

Jonathan FW, Wendel NF. Visualization and interpretation of plants isozymes. In: Soltis DE, Solits PS, editors. Isozymes in Plant Biology. London: Chapman and Hall; 1990. p. 5-45.

Karakish EA.Taxonomic Studies on the Scrophulariaceae. Ph.D. Thesis, Faculty of Science. Egypt: Ain Shams University; 1993. p. 212.

Kasem WT. Anatomical, pollen grains and seed exomorphic studies on five species of Cleome L (Cleomaceae) collected from South West of Saudi Arabia. J Plant Sci 2016;4:29-36.

Kaya A, Dirmencl T. Nutlet surface micromorphology of the genus Nepeta L. (Lamiaceae) in Turkey. Turk J Bot 2008;32:103-12.

Koul K, Nagpal R, Raina SN. Seed coat microsculpturing in Brassica and allied genera (subtribe Brassicinae, Raphaninae, Moricandiinae). Ann Bot 2000;86:385-97.

Madeline MH, Paton A, HarleyRM, Cade PG. Pollen morphological studies in tribe Ocimeae (Nepetoideae: Labiatae): I. Ocimum. Grana 1992;31:161-76.

Masrahi YS. A Brief Illustrate to Wild Plants in Jazan Region.
Jeddaha: King Fahad Library; 2012. p. 302.

Mayer AM, Mayber PA. The Germination of Seeds. $2^{\text {nd }}$ ed. New York: Pergamon Press; 1975.

Moore PD, Webb JA. An Illustrated Guide to Pollen Analysis. London: Hodder and Stoughton; 1978. p. 133.

Abd El-Zaher MA, Badr A, El-Galaly MA, Mobarak AA, Hassan MG. Genetic diversity among ocimum populations in Egypt as reflected by morphological, seed proteins and isozyme polymorphism. Int J Bot 2006;2:261-9.

Patel GI, Datta RM. Pollen grain studies in various types of Corchorus olitorius L., C. capsularis L. And some other species of Corchorus. Grana Palynol 1958;1:18-24:18-24.

Shaheen AM. Taxonomic implication of seed coat characters in native and naturalized species of Solanum L. Taeckholmia 2002;22:131-40.

Sowunmi MA. Pollen grains of Nigerian plants. Grana 1973;13:145-86.

Stearn WT. Botanical Latin. London: David and Charles Book; 1992.

Stegemann H, Burgermeister W, Akbar A. Gel electrophoresis between two glass plates. Z Naturforsch 1988;28:722-32. 